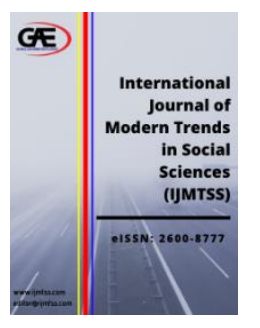

\author{
International Journal of Modern Trends in \\ Social Sciences (IJMTSS) \\ Journal Website: http://ijmtss.com/ \\ eISSN: $2600-8777$
}

\title{
RELIABILITY AND VALIDITY OF INSTRUMENT FOR ASSESSING CUSTOMERS' SATISFACTION, TRUST AND PURCHASE INTENTION ON UMRAH TRAVEL AGENCIES WEBSITE FEATURES
}

\author{
Muhammad Saufi Anas', Hassnah Wee² \\ 1 Faculty of Hotel and Tourism Management, Universiti Teknologi MARA (UiTM), Malaysia \\ Email: saufianas94@ymail.com \\ 2 Faculty of Hotel and Tourism Management, Universiti Teknologi MARA (UiTM), Malaysia \\ Email: hassnah739@uitm.edu.my
}

\section{Article Info:}

Article history:

Received date:. 15.01.2020

Revised date: 19.01.2020

Accepted date: 04.02.2020

Published date: 15.03.2020

To cite this document:

Anas, M. S., \& Wee, H. (2020). Reliability And Validity Of Instrument For Assessing Customers' Satisfaction, Trust And Purchase Intention On Umrah Travel Agencies Website Features. International Journal of Modern Trends in Social Sciences, 3 (11), 50-68.

DOI: $10.35631 / \mathrm{IJMTSS} .311004$.

\begin{abstract}
:
Online shopping has become a prominent consumer market in purchasing travel-related products and is likely to become the largest market in the future. Website quality and evaluation on the travel agency website features have generally been recognized as a critical step to drive business online because it will influence customers' trust-building process and satisfaction level. There are a total of 274 travel agencies currently registered with the Ministry of Tourism and Culture (MOTAC) to provide the Umrah package in Malaysia. Due to a very competitive online travel package offers to Muslim pilgrimage for Umrah purpose, fraud packages have become a vital issue in the Malaysian market. Therefore, this study intends to develop an effective instrument to measure the Umrah Travel Agency website features based on customer satisfaction, trust, and the customers' intention to purchase the Umrah package. Some essential website features identified from previous literature are outlined in this study, such as ease of use, visual appeal, information quality, and information relevancy. A quantitative method using a self-administered survey has been used to collect data from 100 local Muslim youths. The instruments' validity, reliability, and normality of the data were analyzed by using SPSS software. The final result indicated that all 61 instruments in the questionnaire are reliable to be used in the actual study.
\end{abstract}

Keywords:

Pilot Study, Website Features, Satisfaction, Trust, Purchase Intention

\section{Introduction}

In the modern technological world nowadays, travelers are more likely to make purchase transactions and search for additional information for their visit through the internet (Xiang, 
Magnini \& Fesenmaier, 2015). Such situations finally make tour industry players decided to use the internet as an initiative to continue their business (Amaro \& Duarte, 2015). This similar view is also explained by Buhalis and Law (2008), which states that the internet nowadays is an effective marketing platform to connect businesses with their customers.

In line with the above notions, internet usage in the travel business is essential as tourism is classified as intangible, which is a product that is not physically inert. Abubakar (2016) stressed that this would make it difficult for customers to ensure the quality of the tour product before they purchase it. To cope with this situation, they will be more likely to get additional information through the internet before they decide to buy the related travel packages (Casalo, Flavian, Guinaliu \& Ekinci, 2015). To help potential customers search for the information that they need, they must use the website, which also known as an essential platform for information, communication, promotion, sales, and distribution (Benevolo \& Spinelli, 2018).

However, according to Baggio, Mottironi, and Corigliano (2011), it is undeniable that there are still some issues regarding customer satisfaction towards the website. This situation needs to be noted by the industry player because customer satisfaction is known as a customer response that will make them more likely to make a purchase (Chang \& Cheng, 2008). Moreover, it can also cause potential customers to turn to the company competitors if they are dissatisfied with the website that they use (Anderson \& Srinivasan (2003). There are several necessary features for ensuring customers satisfaction such as ease of use (Satghare \& Sawant, 2019), visual appeal (Gangwar \& Date, 2016), information quality (Wang \& Liao, 2008) and information relevancy (Tanford, Baloglu \& Erdem, 2012) involving the content of the website.

Besides paying attention to customer satisfaction with the company's website, customer trust is also undoubtedly associated with the use of the internet. It is because the customer's trust in a website is considered as essential for business because customers will only make purchases once they trust the platform (Kim, Chung \& Lee, 2011). Trust is also considered as a benchmark of the success of an online business-to-consumer or known as B2C relationship, which will create an incentive for potential customers to make purchases on travel packages offered on official travel agency websites (Chen, 2006).

Therefore, this study focuses on the early findings of the study for customers' satisfaction and trust towards Umrah Travel Agency website features to create an intention to purchase the Umrah packages offered by them. Studies involving customer satisfaction and trust in the Umrah travel packages offered on the website should be given attention, especially in Malaysia, as Umrah is encouraged for every Muslim to perform. Due to the Muslim population in Malaysia, accounting for $61.3 \%$ of the total population (Department of Statistic Malaysia, 2018), the Umrah tourism package has become a profitable sales package. However, due to these benefits, some irresponsible people or companies have taken the opportunity to commit fraud travel packages and have raised the issue of trust in the existing Umrah tourism package.

In line with the above notions, the ever-growing Umrah fraud package cases have created a sense of disbelieving toward Umrah Travel Agency, especially those who have just started a business. However, research on Umrah tourism packages that use the website as a marketing platform is still lacking. Therefore, to obtain a more explicit study of this issue, a pilot study should be conducted to ensure that the instruments used in the original research questionnaire form are appropriate. A pilot study is also known as a "dress rehearsal" for a study because it involves a small-scale study conducted before the actual study is conducted. 
The instrument development is a vital component in the research process. The instrument is the tool of collecting data that should be valid and reliable in order to ensure successful research. Validity is the degree that indicates in which a test measure what supposed to measure or set of measures correctly represent the concept of the study. In contrast, the reliability relates to the consistency of the measure(s) (Hair, Black, Babin \& Anderson, 2010). Besides, these authors stressed that data set involved in the study should be well-modeled by a normal distribution as it is the benchmark for statistical methods. As such, a pilot study is required. This pilot study aims to achieve several objectives, such as testing the validity, reliability and normality of the instrument of study. Besides, this pilot study is also intended to provide a preliminary view of the upcoming survey. Therefore, the researcher will be able to minimize errors, such as inappropriate items in the questionnaire. In fact, according to Mathiyazhagan and Nandan (2010), a pilot test or pilot study aims to strengthen all the items in the questionnaire used and at the same time, help facilitate future analysis. For these reasons, the purpose of this study is to develop an effective instrument to measure the Umrah Travel Agency website features based on customer satisfaction, trust, and the customers' intention to purchase the Umrah package. There are two research questions established for this study:

1. What is the reliability and validity evidence of the developed instrument to measure the Umrah Travel Agency website features based on customer satisfaction, trust, and the customers' intention to purchase the Umrah package?

2. Do the data involved in the research is in normal distribution?

There are seven main factors used in the analysis of the reliability, validity and normality of the study. The factors are ease of use, visual appeal, information quality, information relevancy, customers' satisfaction, trust and purchase intention. The related literature of these factors and reliability, validity and normality test results are presented in this paper.

\section{Literature Review}

\section{Pilot Study}

Before the finalized questionnaire is distributed to the respondent for data collection purposes, the pilot test, also known as a pre-test, should be performed first to facilitate and assist the researcher in reducing errors such as inappropriate items in the questionnaire. The purpose of the pilot test is also to consolidate all items in the questionnaire and at the same time, help to ease the analysis process (Mathiyazhagan \& Nandan, 2010).

Therefore, this study aims to test the reliability, validity and normality of the instruments, which will prove that all the items used in the questionnaire are appropriate for use in the actual study.

\section{Umrah in Malaysia}

According to five pillars of Islam, a Muslim who is capable should visit Makkah to perform Hajj (Kamus, 2009). Moreover, Umrah is known as a voluntary visit and which can be done anytime with the only exclusion on the seasons of Hajj, but it is a much similar way with the Hajj ritual, which been keep practice (Almuhzi \& Alsawafi, 2017).

Based on the data received from MOTAC (2017), a total of 250,000 Malaysian Muslims were performing Umrah in 2016. There are 274 travel agencies offered Umrah packages nationwide (MOTAC, 2019). Despite having many authorized companies and licenses to offer Umrah 
packages in Malaysia, there are still many cases of Umrah fraud packages going on in Malaysia. Therefore, real Umrah Travel Agency needs to play an essential role in ensuring the belief of future pilgrims against their company through the use of the website as a marketing platform.

\section{Tourism Website}

Tourism is categorized as an intangible product, where it makes customers challenging to ensure the quality of the product before they buy it (Abubakar, 2016). Thus, Casalo, Flavian, Guinaliu, and Ekinci (2015) argue that customers need to find additional information first before deciding to make purchases over the internet. This situation also makes the tourism industry known as an information-based industry as tourists are required to search for information through their travel location before making a purchase (Werthner \& Klein, 1999).

In line with the above notions, Umrah Travel Agencies in Malaysia need to provide an official company website to be a medium of information on travel packages like Umrah and information about company backgrounds. According to Majlis Kawal Selia Umrah (MKSU) (2010), future pilgrims need to conduct a background check on tour companies that provide Umrah packages first before they deal with the travel agency so they cannot be deceived. Due to the cost of development and annually hosting fees for the website that reaches almost RM1600 a year (Malaysia Developer, 2018), which requires a company with only stable financial resources to manage it.

\section{Ease of Use}

Ease of use is a feature which related, effortlessness for potential customers to search for information, use and navigate the website, which will also encourage them to revisit (Yoo \& Donthu, 2001; Satghare \& Sawant, 2019). Even according to Satghare and Sawant (2019), ease of use is a significant feature to ensure the success of the company website and guarantee that the website is useful. It is evident in a study conducted by Agag and El-Masry (2016), which found that ease of use is one of the significant indicators that can create customer trust on the website. Furthermore, Pham and Ngunyen (2019) also posited that ease of use has a direct effect on repurchase intention on the website.

In the context of this study, ease of use is classified as ease for customers to obtain information, usability, and navigation on the Umrah Travel Agency website. The ease of getting information is vital as the future pilgrims are encouraged by the Majlis Kawal Selia Umrah (MKSU, 2011) to search for the information first and to do some research on the background of the company that offering Umrah packages before making a purchase. Even the travel agencies that are offering Umrah packages also need to show their outbound tourism license, which is a permit to arrange people to travel abroad (MKSU, 2011).

\section{Visual Appeal}

The advancement of internet technology nowadays has affected people to use the website to gain information (Nguyen at al., 2016). This trend has changed the operation of tour operators to provide customers with a good impression of their website. Such reactions can be formed through the development of a well-designed website is an initiative that creates a customer perception and at the same time, embraces a positive response among them (Nguyen et al., 2016; Tran et al., 2015). Additionally, Foroudi and his members (2017) have also revealed in their study that a good website will influence the company's image. Similarly, a well-designed website will have a positive impact on increasing the perceptions of potential customers (Braddy, Meade, \& Kroustalis, 2008; Haq, Raja, Nosheen, \& Sajjad, 2018). 
Customers are likely to get bored when receiving too much information about tourism destinations without encouragement by the destination image because such visual known as a driver for mental development based on the impression received from most of the overall information (Alhemoud \& Armstrong, 1996). It is similar to the destination image, which will affect the overall customer's perception (Lawson \& Baud-Bovy, 1977). Those perceptions or responses can be influenced by the improvement of existing tourism websites (Foroudi et al., 2016). Therefore, Umrah Travel Agency needs to be concerned about visual features on their website, especially while promoting the Umrah packages to influence customer satisfaction.

\section{Information Quality}

Information quality is an essential component in the website evaluation model (Law, 2018). It is a feature based on accuracy, completeness, timeliness, and presentation format in the tourism website (Nelson, Todd, \& Wixom 2005), which can encourage customer reactions as satisfaction and cognitive evaluations (Wang \& Liao, 2008). As had been mentioned before, internet users visit the tourism website because they desire additional information. Then they will have the intention to buy the tour package if they satisfy. Complete information on tourism destinations (Jeong, Oh, \& Gregoire, 2003) and travel agency background (MKSU, 2011) should be provided to ensure booking or purchase intention on tour package. Therefore, the quality of information is considered as the primary factor in establishing customer trust (Smith, 2004).

\section{Information Relevancy}

Information relevancy is also a vital feature to increase customer satisfaction and trust towards the travel website. It is because the tourism product is difficult to ensure the quality before making a purchase and thus creating a high risk for potential travelers. However, the risk of a quality tourism product can be avoided by searching for complete information (Nazalek, 2010). Furthermore, finding complete and relevant information on tourism destinations is indispensable if it involves long distances journeys (Nazalek, 2010).

Therefore, Umrah Travel Agency needs to provide relevant information on their website to satisfy the future pilgrims who are seeking information on their website. The complete and relevant information is needed for future pilgrims because it involves a long-distance journey between Malaysia to Saudi Arabia, which takes at least 9 hours of air travel (Trip.com, 2019). This feature is also closely linked to building customer confidence in Umrah packages provided by Umrah Travel Agency.

\section{Customer's Satisfaction}

The website is the primary platform for internet users to search for information (Kim \& Stoel, 2004). Therefore, the perception of internet users towards website features is an essential indicator of their satisfaction (Lin, 2007). Furthermore, Chang and Cheng (2009) described that customer satisfaction is an effective response to a purchase process, and it is an influential factor for the success of the marketing process. It is similar to a study conducted by Kim and Niehm (2009), they noted that satisfaction is also considered as a measurement tool of the successful business that is not only for a traditional business but also for online business.

Based on the current study, customer satisfaction is known as an outcome given by the buyers based on the services, which are whether it achieves their expectation or not (Haq, Raja, Nosheen \& Sajjad, 2018). 
Thus, Anderson and Srinivasan (2003) stated that customers who are dissatisfied with a website would seek additional information and turn to the company's competitors. To enhance customers' satisfaction with online intention, a company needs to provide up to date and accurate information (Tandon, Kiran \& Sah, 2017). Hence, it is clear that customer satisfaction over the travel website is a vital variable for increasing confidence and thus creating an intention to purchase among customers (Angelova \& Zekiri, 2011).

\section{Customer's Trust}

The concept of trust is a part of a critical success factor of online business-to-consumer or B2C relationships, which will also affect consumers' online behavior such as purchase intention (Chen, 2006). Another study also highlights that trust is a customer's sense of security and their confidence with the performance of travel agencies' websites (de Wulf, Schillewaert, Muylle \& Rangarajan, 2006). Trust is also known as a vital performance of a travel agency website as it affects perceived risk, attitude, and intention customers to purchase travel packages online (Agag \& El-Masry, 2016).

According to McCole (2002), online business or e-commerce websites, primarily involving sales of tourism products which is intangible, hence, the company should develop a clear communication on all forms of transactions such as information on prices, taxes, and other additional charges. Clear communication will affect the selection of the product by reducing the level of uncertainty of information on the website (Tanford, Baloglu \& Erdem, 2012). Those works of literature indicate that the provision of useful information or features will influence the trust among customers.

\section{Purchase Intention}

The development of excellent website features will influence customers to buy the product. It is evident by a recent study stating that the ease of use of the website (Nunkoo \& Ramkissoon, 2013) and trust (Amaro \& Duarte, 2015) are the factors that influence customers to purchase travel packages online. Jensen (2009) also noted that prospective travelers who feel comfortable when using travel agencies' websites are more likely to make online purchases.

Also, the quality tourism website (Yan \& Li-Ming, 2015; Wen, 2009) and customer satisfaction (Chang \& Cheng, 2008) are also factors that influence potential travelers to make online purchases.

According to a study conducted by Jensen (2009), buying travel packages via the internet is influenced by their experience using the website. Therefore, Umrah Travel Agency needs to ensure its web pages are easy to find in search engines because the diversity in website features also affects customer purchase intention (Jensen, 2009).

\section{Methodology}

\section{Research Design}

A good research results obtained through several research method techniques (Williams, 2007). Hence, this study was conducted to examine the validity and reliability of the instruments, which categorized as a cross-sectional study because the variables are only measured at the same point in time (Kumar, Talib \& Ramayah, 2013). This study utilized a convenient sampling method that categorized under non-probability sampling. According to Kumar, Talib \& Ramayah (2013), convenient sampling involves data collection from a population that is easy participating in the study. A self-administered survey questionnaire was the main approach 
used to collect the data for the study. The instruments in the questionnaire established in a bilingual format, which is using Malay and the English language. The translated questionnaire in both languages was checked by an expert translator.

\section{Instrumentation and Measurement of Variables}

Structured questionnaires using closed-ended multiple-choice questions were used to obtain answers to the objectives of this study. A quantitative method using a self-administered survey containing 61 questions were divided into four main areas, such as website features, customers' satisfaction, customers' trust, and purchase intention. All of the questions used in this questionnaire were adapted from previous studies.

This study using a 5-Point Likert scale ranging from "5 = Strongly Agree" to " 1 = Strongly Disagree" was used because it is more appropriate and reliable since most of the items used in this study were intended to measure respondents' perceptions and attitudes (Ibrahim, Ghani, Munir \& Salleh, 2013).

\section{Sampling and Pilot-testing}

The questionnaire used for this pilot study was distributed to respondents comprising Muslim Youth. The reason is because of youth or generation $\mathrm{Y}$ and $\mathrm{Z}$, which is also known as a "netgeneration," which uses the internet as a medium for searching information and makes an online purchase (Monaco, 2018).

As this study was a pilot study, 100 respondents from Muslim youth were selected to participate in this survey. The sample size used in this study is in line with the recommendations by Roscoe (1975) and Sekaran (2003), that sample sizes for pre-test are generally small. However, a sample size greater than 30 is suitable for most research. Therefore, this study used 100 sample sizes to obtain more accurate results for analysis.

\section{Data Collection Process}

The data collection process had been carried out in the public library in Selangor, which provides free internet access to ease the respondent access to the context of this study. Each respondent was approached individually, and the researcher asked for their willingness to involve in this study. Once they agree, the process starts with a pre-asking screening question that requires certainty of whether a respondent has the intention to perform Umrah in the future. This process will help the respondent to gain a more unobstructed view of website features that will enhance their confidence in the Umrah Travel Agency website. After that, the researcher explained the purpose of the study to the respondents. This process went smoothly as respondents consisted of Malaysians who used the same language as the researcher. Therefore, all the information that delivered to them about this study is easier to be understood.

Next, the respondent was given the time and space to answer the questionnaire. However, many of the respondents were able to respond to all of the items within 10 to 12 minutes. During this process, respondents were encouraged to provide any comments or suggestions regarding the items used if they encounter any problems or discrepancies with the items. However, there was little comment received from the respondents, at the same time, indicating that they had no problem with the questionnaire. All completed questionnaires were analyzed for reliability, validity, and normality test using SPSS software version 25. 


\section{Results}

\section{Profiles of Respondent}

Table 1 shows the demographic background of respondents consisting of Muslim youth. Among the 100 respondents, female respondents dominated the sample by $65 \%$ compared to $35 \%$ of male respondents. Most of the respondents between the ages of 20-29 years old had completed this survey by $89 \%$, while the remaining $30-39$ years old respondents were $11 \%$. For marital status, $88 \%$ of them are single, and $12 \%$ are married.

For education level, most of the respondents had a Bachelor's Degree of $69 \%$, followed by a Master's Degree / Doctorate of 15\%, STPM / Matriculation / Diploma of 14\%, and 2\% had SPM.

For occupation data, respondents in this pilot study were a student (68\%), followed by private sector employee (19\%), government servant (6\%), other (housewife, unemployed and farmers) $(4 \%)$ and the last one is own business $(3 \%)$.

Table 1: Demographic Profiles of Respondents

\begin{tabular}{|c|c|c|}
\hline Items & $\begin{array}{c}\text { Frequency } \\
(\mathbf{N}=100)\end{array}$ & $\begin{array}{c}\text { Percentage } \\
(\%)\end{array}$ \\
\hline \multicolumn{3}{|l|}{ Gender } \\
\hline Male & 35 & 35 \\
\hline Female & 65 & 65 \\
\hline \multicolumn{3}{|l|}{ Age } \\
\hline 20-29 years & 89 & 89 \\
\hline 30-39 years & 11 & 11 \\
\hline \multicolumn{3}{|l|}{ Marital Status } \\
\hline Married & 12 & 12 \\
\hline Single & 88 & 88 \\
\hline \multicolumn{3}{|l|}{ Education Level } \\
\hline SPM & 2 & 2 \\
\hline STPM/Matriculation/Diploma & 14 & 14 \\
\hline Bachelor's Degree & 69 & 69 \\
\hline Master's Degree/ Doctorate & 15 & 15 \\
\hline \multicolumn{3}{|l|}{ Occupation } \\
\hline Government Servant & 6 & 6 \\
\hline Private Sector Employee & 19 & 19 \\
\hline Own Business & 3 & 3 \\
\hline Student & 68 & 68 \\
\hline Others (housewife, unemployed, farmers) & 4 & 4 \\
\hline
\end{tabular}

\section{Reliability Test}

The purpose of conducting reliability analysis is to identify the internal consistency in items that measure the concept (Mahmud, 2008). One of the most popular tests for test inter-item consistency reliability is Cronbach's coefficient alpha, which is used for multipoint-scale items (Sekaran, 2003). The item is considered highly correlated when it been answered consistently by respondents. In line with the above notions, to determine the reliability of the instruments, the minimum cut-off value of 7.0 Cronbach's coefficient of alpha had been used (Nunnally. 1978). Furthermore, George and Mallery (2003) have suggested the Cronbach's coefficient of 
alpha indicators that can be used to classify the range of value for the internal consistency of items as presented in Table 2.

Table 2: Cronbach's Coefficient of Alpha Indicators for Internal Consistency

\begin{tabular}{cc}
\hline Cronbach's Alpha & Internal Consistency \\
\hline $\boldsymbol{\alpha}>\mathbf{0 . 9}$ & Excellent \\
$\mathbf{0 . 8}<\boldsymbol{\alpha}<\mathbf{0 . 9}$ & Good \\
$\mathbf{0 . 7}<\boldsymbol{\alpha}<\mathbf{0 . 8}$ & Acceptable \\
$\mathbf{0 . 6}<\boldsymbol{\alpha}<\mathbf{0 . 7}$ & Questionable \\
$\mathbf{0 . 5}<\boldsymbol{\alpha}<\mathbf{0 . 6}$ & Poor \\
$\boldsymbol{\alpha}<\mathbf{0 . 5}$ & Unacceptable \\
\hline
\end{tabular}

After performing the data analysis using SPSS version 25, results indicated that all items had a high-reliability standard of 0.865 to 0.964 , which is referring to the Good and Excellent range of rating indicated in Table 3. This result is also in line with Sekaran and Bougie (2010), which stated that the ratio of 0.70 and above indicates that the items used have high standard reliability. Therefore, all items used are reliable and do not need to remove any items based on the value of Alpha. The researcher will only make small improvements to the size of the font writing and the layout of the questionnaire to facilitate the reading and comfort of the respondents. Thus, it is evident that the instrument fit to be used for the actual study.

Table 3: Alpha Value for each variable in questionnaire design

\begin{tabular}{cccc}
\hline Section & Variables & Number of Items & Alpha Value \\
\hline \multirow{3}{*}{ B } & Ease of Use & 5 & 0.900 \\
& Visual Appeal & 5 & 0.877 \\
& Information Quality & 5 & 0.865 \\
& Information Relevancy & 6 & 0.873 \\
\hline \multirow{2}{*}{ C } & Satisfaction & 23 & 0.964 \\
& Trust & 12 & 0.955 \\
\hline
\end{tabular}

\section{Normality Test}

The normality test used in this study was to determine whether the dataset used was normally distributed for this study. Furthermore, most statistical analysis techniques require the normality assumption analysis (Tabachnick \& Fidell, 2007; Maiyaki \& Mokhtar, 2010). Each variable used in the study is approximately normally distributed if the Skewness and Kurtosis statistic values are within the range of \pm 2.0 (Pallant, 2010). The commonly used measurable tool to measure the normality of the variable is standard Q-Q plots. If the majority observed values or small dots are in parallel on the straight line in the Q-Q plots, the variables are considered normally distributed (Pallant, 2010). 
Table 4: Normality Analysis Result of the Variables

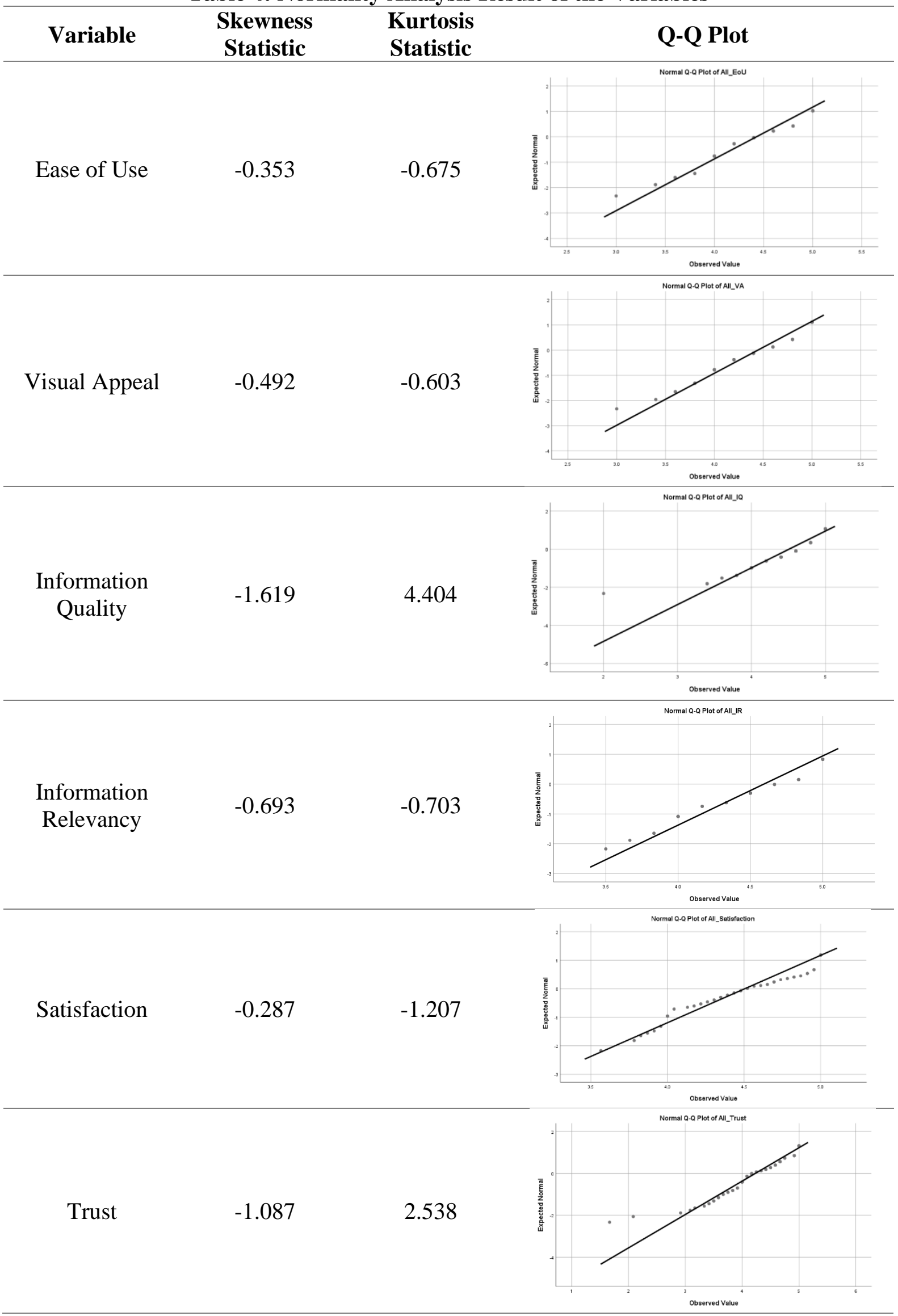


Purchase

Intention
$-0.827$

0.039

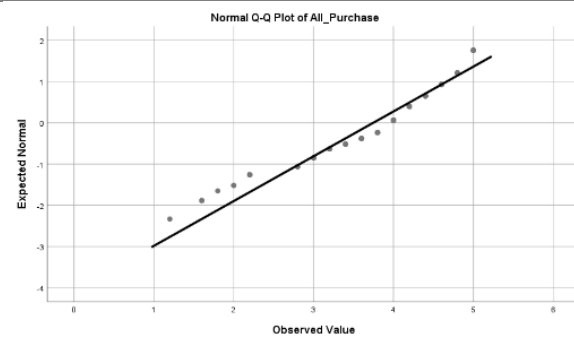

Based on Table 4, the Kurtosis and Skewness Statistic values for all variables used in this study were within the range \pm 2.00 ; therefore, all of the variables were normally distributed. Looking at the Normal Q-Q plot, the majority of observed values or smaller dots in a normal distribution.

\section{Descriptive Statistic}

The critical thing for statistical analysis is to do a descriptive analysis to see the mean and standard deviation of each variable that been used in the study (Sekaran, 2003). In other words, descriptive statistics could be used to manage the data and visualized it into a summarized table. The measured was computed using the mean score to obtain the appropriate value for represented the situation of the study.

Table 5: Descriptive Statistic

\begin{tabular}{ccc}
\hline Variables & Mean & Standard Deviation \\
Ease of Use & 4.43 & 0.49 \\
Visual Appeal & 4.45 & 0.48 \\
Information Quality & 4.51 & 0.52 \\
Information Relevancy & 4.59 & 0.43 \\
Satisfaction & 4.50 & 0.42 \\
Trust & 4.23 & 0.63 \\
Purchase Intention & 3.75 & 0.92
\end{tabular}

Referring to table 5, Ease of Use $(M=4.43, S D=0.49)$, Visual Appeal $(M=4.45, S D=0.48)$, Information Quality $(M=4.51, S D=0.52)$, Information Relevancy $(M=4.59)$, Satisfaction $(\mathrm{M}=4.50, \mathrm{SD}=0.42)$ and Trust $(\mathrm{M}=4.23, \mathrm{SD}=0.63)$ had an average mean scores between $\mathrm{M}=4.23$ to $\mathrm{M}=4.59$. This situation indicates that the respondents involved in this pilot study agreed with all the variables used as the mean score showed a high-level value close to the maximum average score of 5.0. Even though, Purchase Intention $(\mathrm{M}=3.75, \mathrm{SD}=0.92)$ had the lowest mean value over the other variables, but its value was still considered to be higher than 3.0. Hence, it can be seen that all the variables used in this study showed a mean value greater than 3.0, thus qualifying all items and variables used in this study for the future research.

\section{Conclusion}

Umrah is a worship practice that Islam encourages for its believers who capable of visiting the Holy City of Makkah in Saudi Arabia. Therefore, it is undeniable that a travel agency that provides Umrah tourism packages can make a vast profit, which there are companies take the opportunity to sell an Umrah fraud package to make profit. Accordingly, the Umrah Regulatory Council (MKSU) in 2010 encouraged the future pilgrims to conduct background checks on the travel agencies before making their purchase. Several websites feature such as ease of use, visual appeal, information quality, and information relevancy are expected to create customer satisfaction as well as build trust, while also creating an intention to purchase the Umrah package offered on the travel agencies website. 
This study focuses on testing each variable used in the questionnaire to help get a more precise answer to the actual study. Besides, this pilot study is focused on the value of validity, reliability, and normality test, which is an essential aspect of ensuring the accuracy of the survey questionnaire items from any errors before the actual study. This process also aims to determine the level of appropriateness of using questionnaire structures to get the right response from the respondents. The accuracy of the items used in the questionnaire can provide accurate data and at the same time, produce good research results.

The results of the reliability test indicate that all 61 items in this study are reliable to be used in the instrument for the actual study. The pilot study results revealed that all the items involved have a Cronbach Alpha value of 0.867 to 0.964, which is above the minimum Cronbach Alpha value of 0.70 . On the normality test, the results of the Q-Q plot show that the data collected is in a normal distribution. In fact, in the descriptive analysis, all the variables involved showed high mean values of 3.75 to 4.59 from the maximum values of 5.00.

It is possible to conclude that the 61 items in the questionnaire are reliable to use in the actual study. However, only minor corrections on the text size and structure required. Through this conclusion, the instrument is valid and reliable to proceed with the actual study and hope that the results from the final survey will be able to fulfil the expected outcome based on the established objective, research question, and hypothesis.

\section{References}

Abubakar, A. (2016). Does eWOM influence destination trust and travel intention: a medical tourism perspective. Economic research-Ekonomska istraživanja, 29(1), 598-611.

Agag, G. M., \& El-Masry, A. A. (2017). Why do consumers trust online travel websites? Drivers and outcomes of consumer trust toward online travel websites. Journal of Travel Research, 56(3), 347-369.

Alhemoud, A. M., \& Armstrong, E. G. (1996). Image of tourism attractions in Kuwait. Journal of travel Research, 34(4), 76-80.

Almuhrzi, H. M., \& Alsawafi, A. M. (2017). Muslim perspectives on spiritual and religious travel beyond Hajj: Toward understanding motivations for Umrah travel in Oman. Tourism Management Perspectives, 24, 235-242.

Amaro, S., \& Duarte, P. (2015). An integrative model of consumers' intentions to purchase travel online. Tourism management, 46, 64-79.

Anderson, R. E., \& Srinivasan, S. S. (2003). E-satisfaction and e-loyalty: A contingency framework. Psychology \& Marketing, 20, 123-138.

Angelova, B. \& Zekiri, J. (2011), Measuring customer satisfaction with service quality using American Customer Satisfaction Model (ACSI Model). International Journal of Academic Research in Business and Social Sciences, Vol. 1 (3), p. 232.

Aziz, N. S., \& Kamaludin, A. (2016). Validation of Questionaire for Website Usability (QWU) Instrument Based on Experts Review. In Advanced Computer and Communication Engineering Technology, 891-902.

Baggio R, Mottironi C \& Antonioli Corigliano M (2011) Technological aspects of public tourism communication in Italy. Journal of Hospitality and Tourism Technology 2(2): $105-119$.

Benevolo, C., \& Spinelli, R. (2016). Evaluating the quality of web communication in nautical tourism: A suggested approach. Tourism and Hospitality Research, 18(2), 229-241. 
Braddy, P. W., Meade, A. W., \& Kroustalis, C. M. (2008). Online recruiting: The effects of organisational familiarity, website usability, and website attractiveness on viewers' impressions of organisations. Computers in Human Behaviour, 24(6), 2992-3001.

Buhalis, D., \& Law, R. (2008). Progress in information technology and tourism management: 20 years on and 10 years after the Internet-The state of eTourism research. Tourism Management, 29(4), 609-623.

Casaló, L.V., Flavián, C., Guinalíu, M., \& Ekinci, Y. (2015). Do online hotel rating schemes influence booking behaviors? International Journal of Hospitality Management, 1(49), $28-36$.

Chen, C. (2006). Identifying Significant Factors Influencing Consumer Trust in an Online Travel Site. Information Technology and Tourism 8:197-214.

Corritore, C. L., Marble, R. P., Wiedenbeck, S., Kracher, B., \& Chandran, A. (2005). Measuring online trust of websites: Credibility, perceived ease of use, and risk. AMCIS 2005 proceedings, 370 .

Cyr, D. (2013). Website design, trust and culture: An eight country investigation. Electronic Commerce Research and Applications, 12(6), 373-385.

Cyr, D., Kindra, G. S., \& Dash, S. (2008). Web site design, trust, satisfaction and e-loyalty: the Indian experience. Online Information Review, 32(6), 773-790

De Wulf, K., Schillewaert, N., Muylle, S., \& Rangarajan, D. (2006). The role of pleasure in web site success. Information \& Management, 43, 434-446.

Department of Statistics of Malaysia. (2011, July 29). The population of Malaysia based on religion.

Retrieved

from https://www.dosm.gov.my/v1/index.php?r=column/cthemeByCat\&cat=117\&bul_id= MDMxdHZjWTk1SjFzTzNkRXYzcVZjdz09\&menu_id=L0pheU43NWJwRWVSZkl WdzQ4TlhUUT09

Foroudi, P., Dinnie, K., Kitchen, P. J., Melewar, T. C., \& Foroudi, M. M. (2017). IMC antecedents and the consequences of planned brand identity in higher education. European Journal of Marketing, 51(3), 528-550.

Foroudi, P., Gupta, S., Kitchen, P., \& Nguyen, B. (2016). A framework of place branding, place image, and place reputation: Antecedents and moderators. Qualitative Market Research: An International Journal, 19(2), 241-264.

Gangwar, H., \& Date, H. (2016). Critical factors of cloud computing adoption in organizations: An empirical study. Global Business Review, 17(4), 886-904.

George, D., \& Mallery, P. (2003). SPSS for Windows step by step: A simple guide and reference. Boston, MA: Allyn \& Bacon.

Hair, J.F., Black, W.C., Babin, B.J., \& Anderson, R.E. (2010). Multivariate Data Analysis. Seventh Edition. Prentice Hall, Upper Saddle River, New Jersey.

Haq, N. U., Raja, A. A., Nosheen, S., \& Sajjad, M. F. (2018). Determinants of client satisfaction in web development projects from freelance marketplaces. International Journal of Managing Projects in Business, 11(3), 583-607.

Heijden, H., Verhagen, T., \& Creemers, M. (2003). Understanding online purchase intentions: contributions from technology and trust perspectives. European journal of information systems, 12(1), 41-48.

Ibrahim, R. M., Ghani, M. A., Munir, A., \& Salleh, M. (2013). Organizational Citizenship Behavior among Local Government Employees in East Coast Malaysia: A Pilot Study, International Business Research, 6(6), 83-94.

Jensen, J. M. (2009). Travellers' intentions to purchase travel products online: The role of shopping orientation. In A. Matias, P. Nijkamp \& M. Sarmento (Eds.), Advances in tourism economics: New developments, 203-215. Heidelberg: Physica Verlag. 
Jeong, M., Oh, H., \& Gregoire, M. (2003). Conceptualizing web site quality and its consequences in the lodging industry. International Journal of Hospitality Management, 22(2), 161-175.

Kamus, I. (2009), Indahnya Hidup Bersyariat. Telaga Biru (ISBN 9789675102301).

Kim, H., \& Niehm, L.S. (2009). The impact of website quality on information quality, value, and loyalty intentions in apparel retailing. Journal of Interactive Marketing, 23(3), 221233.

Kim, M. J., N. Chung, \& C. K. Lee. (2011). The Effect of Perceived Trust on Electronic Commerce: Shopping Online for Tourism Products and Services in South Korea. Tourism Management 32 (2): 256-65.

Kim, S. \& Stoel, L. (2004), Apparel retailers: website quality dimensions and satisfaction, Journal of Retailing and Consumer Services, 11 (2), pp. 109-17.

Kumar, M., Talib, S. A., \& Ramayah, T. (2013). Business Research Methods. Selangor: Oxford Fajar.

Law, R. (2018). Evaluation of hotel websites: progress and future developments (invited paper for 'luminaries' special issue of International Journal of Hospitality Management). International Journal of Hospitality Management, 76(Part B), 2-9.

Lawson, F., \& Baud-Bovy, M. (1977). Tourism and Recreation Development. Architectural Press.

Lee, Y., \& Kozar, K. a. (2012). Understanding of website usability: Specifying and measuring constructs and their relationships. Decision Support Systems, 52(2), 450-463.

Lin, H.-F. (2007), The impact of website quality dimensions on customer satisfaction in the B2C e-commerce context, Total Quality Management and Business Excellence, 18 (4), pp. 363-78.

Liu, I. F., Chen, M. C., Sun, Y. S., Wible, D., \& Kuo, C. H. (2009). Extending the TAM model to explore the factors that affect Intention to Use an Online Learning Community. Computers \& education, 54(2), 600-610.

Loiacono, E., Watson, R., \& Goodhue, D. (2007). WebQual: An Instrument for Consumer Evaluation of Web Sites. International Journal of Electronic Commerce, 11(3), 5187.doi:10.2753/JEC1086-4415110302

Mahmud, Z. (2008). Handbook of research methodology: A simplified version. Selangor: UiTM Press.

Maiyaki, A. A., \& Mohd Mokhtar, S. S. (2010). Determinants of Customer Behavioural Responses: A Pilot Study. International Business Research, 4(1), p193

Malaysia Developer. (2018). Pakej \& Harga - Malaysia Web Developer - Pereka Laman Web Malaysia. Retrieved from http://www.malaysiadeveloper.com/pakej-harga

McCole, P. (2002). The Role of Trust for Electronic Commerce in Services. International Journal of Contemporary Hospitality Management, 14: 81-87.

MKSU. (2010). Slide Kesedaran Penipuan Pakej Umrah [Slide about Umrah Package Awareness]. Retrieved from http://umrahmksu.motac.gov.my/panduan/kesedaranpenipuan-pakej-umrah

MOTAC. (2017). Ministry of Tourism and Cultural Specification of Special License of Umrah and Integrated Information Management System for Hands from Umrah. Retrieved from https://www.tourism.gov.my/media/view/kementerian-pelancongan-dankebudayaan-perkenal-lesen-khas-umrah-dan-sistem-pengurusan-maklumat-bersepaduuntuk-tangani-penipuan-umrah

MOTAC. (2019). Senarai Agensi Pengendali Umrah dan Ziarah [List of Umrah Arrangement Agencies and Pilgrims]. Retrieved 1 June, 2019, from http://umrahmksu.motac.gov.my/agensi 
Nalazek, M. (2010). Internetowe kanaty dystrybucji na rynku turystycznym [Internet-based distribution channels on the travel market]. Warszawa: Difin.

Nguyen, B., Melewar, T. C., Japutra, A., Han, S. H., Chen, C. H. S., \& Yu, X. (2016). An investigation of the corporate identity construct in China: Managerial evidence from the high technology industry. Journal of Marketing Communications, 1-22 (March).

Nunkoo, R., \& Ramkissoon, H. (2013). Travelers' E-purchase intent of tourism products and services. Journal of Hospitality Marketing \& Management, 22, 505-529.

Nunnally, J. (1978). Psychometric theory. New York: McGraw-Hill.

Pham, H., \& Nguyen, T. (2019). The effect of website quality on repurchase intention with the mediation of perceived value: The case study of online travel agencies in Vietnam. Journal of Global Business Insights, 4(1), 78-91.

Satghare, H. R., \& Sawant, M. (2019). Evaluation of official destination website of Maharashtra state (India) from the customer perspectives. Journal of Global Scholars of Marketing Science, 29(2), 234-247.

Sekaran, U. (2003). Research Methods for Business: A Skill Building Approach (Fourth Edi). New York: John Wiley \& Sons, Inc.

Sekaran, U., \& Bougie, R. (2010). Research Methods for Business: A Skill Building Approach, 5th Edition. John Wiley and Sons.

Smith, A.D. (2004). Information exchanges associated with Internet travel marketplaces. Online Information Review, 28(4), 292-300.

Tabachnick, B. G., \& Fidell, L. S. (2007). Using Multivariate Statistics. Pearson/Allyn \& Bacon.

Tandon, U., Kiran, R., \& Sah, A. N. (2017). Customer satisfaction as mediator between website service quality and repurchase intention: An emerging economy case. Service Science, 9(2), 106-120.

Tanford, S., S. Baloglu \& M. Erdem. (2012). Travel Packaging on the Internet: The Impact of Pricing Information and Perceived Value on Consumer. Journal of Travel Research, 51: $68-80$.

Tran, M. A., Nguyen, B., Melewar, T. C., \& Bodoh, J. (2015). Exploring the corporate image formation process. Qualitative Market Research: An International Journal, 18(1), 86114.

Trip.com. (n.d.). Flight from Malaysia to Jeddah. Retrieved January, 2019, from https://my.trip.com/flights/jeddah-to-kuala-lumpur/tickets-jed-kul/?startdate=201902-05

Wang, Y. S., Tang, T. I., \& Tang, J. T. E. (2001). An instrument for measuring customer satisfaction toward web sites that market digital products and services. J. Electron. Commerce Res., 2(3), 89-102.

Wang, Y.S., \& Liao, Y.W. (2008). Assessing e-government systems success: A validation of the DeLone and McLean model of information systems success. Government Information Quarterly, 25(4), 717-733.

Wen, I. (2009). Factors affecting the online travel buying decision: A review. International Journal of Contemporary Hospitality Management, 21, 752-765.

Werthner, H., \& Klein, S. (1999). Information technology and tourism: A challenging relationship. Vienna: Springer.

Williams, C. (2007). Research methods. Journal of Business \& Economics Research (JBER), $5(3)$.

Xiang, Z., Magnini, V. P., \& Fesenmaier, D. R. (2015). Information technology and consumer behavior in travel and tourism: Insights from travel planning using the internet. Journal of Retailing and Consumer Services, 22, 244-249. 
Yan, M. L., \& Li-Ming, A. K. (2015). Leisure Tourists' Online Buying Intentions in Malaysia. The Journal of Developing Areas, 49(5), 321-333.

Yoo, B. \& Donthu, N. (2001) Developing a Scale to Measure the Perceive Quality of an Internet Shopping Site (SITEQUAL). Quarterly Journal of Electronic Commerce, 2, 31-47.

\section{Appendix}

\begin{tabular}{|c|c|}
\hline Items & Sources \\
\hline \multicolumn{2}{|l|}{ Ease of Use } \\
\hline $\begin{array}{l}\text { I should easily find the information needed from the } \\
\text { website. }\end{array}$ & $\begin{array}{c}\text { Aziz and } \\
\text { Kamaludin,(2015) }\end{array}$ \\
\hline I should easily navigate the website anywhere and anytime. & $\begin{array}{c}\text { Cyr (2013), } \\
\text { Aziz and Kamaludin } \\
(2015)\end{array}$ \\
\hline $\begin{array}{l}\text { I think the website should provide good navigation facilities } \\
\text { for information content. }\end{array}$ & $\begin{array}{c}\text { Cyr (2013), } \\
\text { Aziz and Kamaludin } \\
(2015)\end{array}$ \\
\hline $\begin{array}{l}\text { I think that the website links should be consistent and easy } \\
\text { to identify. }\end{array}$ & $\begin{array}{c}\text { Meyes (2009) } \\
\text { Aziz and Kamaludin } \\
(2015)\end{array}$ \\
\hline I should feel easy to understand how to use the website. & Corritore et al. (2005) \\
\hline \multicolumn{2}{|l|}{ Visual Appeal } \\
\hline The text on the website should be easy to read. & $\begin{array}{c}\text { Lioacono et al. (2007) } \\
\text { Aziz and Kamaludin } \\
(2015)\end{array}$ \\
\hline $\begin{array}{l}\text { The website should use color and structures that are } \\
\text { comfortable to watch. }\end{array}$ & $\begin{array}{c}\text { Lee and Kozar (2012) } \\
\text { Aziz and Kamaludin } \\
(2015)\end{array}$ \\
\hline $\begin{array}{l}\text { The layout of the web pages should make the information } \\
\text { searching process more comfortable. }\end{array}$ & $\begin{array}{l}\text { Liu, Chen, Sun, Wible } \\
\text { and Kuo (2009) }\end{array}$ \\
\hline $\begin{array}{l}\text { The website should look professionally designed and well } \\
\text { presented. }\end{array}$ & Cyr and Dash (2008) \\
\hline $\begin{array}{l}\text { The product information provided on the website should be } \\
\text { presented consistently and logically. }\end{array}$ & Cyr and Dash (2008) \\
\hline \multicolumn{2}{|l|}{ Information Quality } \\
\hline $\begin{array}{l}\text { The contents provided by the website should be easily } \\
\text { understood. }\end{array}$ & $\begin{array}{c}\text { Lee and Kozar (2012) } \\
\text { Aziz and Kamaludin } \\
(2015)\end{array}$ \\
\hline The website content should reflect company expertise. & Corritore et al. (2005) \\
\hline The website should provide accurate information. & $\begin{array}{l}\text { Wang, Tang and Tang } \\
(2001)\end{array}$ \\
\hline The website should provide up-to-date information. & $\begin{array}{l}\text { Wang, Tang and Tang } \\
(2001)\end{array}$ \\
\hline The website information should adequately meet my need. & $\begin{array}{l}\text { Wang, Tang and Tang } \\
\text { (2001) }\end{array}$ \\
\hline
\end{tabular}




\begin{tabular}{|c|c|}
\hline \multicolumn{2}{|l|}{ Information Relevancy } \\
\hline The website should provide truthful information. & Corritore et al. (2005) \\
\hline The website should reflect integrity & Corritore et al. (2005) \\
\hline $\begin{array}{l}\text { The information provided by the website should be } \\
\text { believable. }\end{array}$ & Corritore et al. (2005) \\
\hline $\begin{array}{l}\text { The website should provide clear transaction and price } \\
\text { information. }\end{array}$ & $\begin{array}{l}\text { Wang, Tang and Tang } \\
\text { (2001) }\end{array}$ \\
\hline $\begin{array}{l}\text { The website should provide clear company background } \\
\text { information. }\end{array}$ & $\begin{array}{l}\text { Wang, Tang and Tang } \\
\text { (2001) }\end{array}$ \\
\hline $\begin{array}{l}\text { The website should provide clear Umrah package } \\
\text { information (Distance of hotel, type of accommodation, type } \\
\text { of flight and many more) }\end{array}$ & $\begin{array}{l}\text { Aziz and Kamaludin } \\
\qquad(2015)\end{array}$ \\
\hline \multicolumn{2}{|l|}{$\begin{array}{l}\text { Satisfaction } \\
\end{array}$} \\
\hline \multicolumn{2}{|l|}{ Ease of Use } \\
\hline $\begin{array}{l}\text { I will satisfy if the website provides convenient search } \\
\text { engines to search for product or service review. }\end{array}$ & $\begin{array}{l}\text { Wang, Tang and Tang } \\
\text { (2001) }\end{array}$ \\
\hline $\begin{array}{l}\text { I will satisfy if the website can make it easy to find the } \\
\text { information needed. }\end{array}$ & $\begin{array}{c}\text { Aziz and } \\
\text { Kamaludin,(2015) }\end{array}$ \\
\hline $\begin{array}{l}\text { I will satisfy if the website can easily navigate at anywhere } \\
\text { and anytime. }\end{array}$ & $\begin{array}{c}\text { Cyr (2013), } \\
\text { Aziz and Kamaludin } \\
(2015)\end{array}$ \\
\hline $\begin{array}{l}\text { I will satisfy if the website can provide excellent navigation } \\
\text { facilities for information content. }\end{array}$ & $\begin{array}{c}\text { Cyr (2013), } \\
\text { Aziz and Kamaludin } \\
(2015)\end{array}$ \\
\hline I will satisfy if the website links are accessible to be search. & $\begin{array}{c}\text { Meyes (2009) } \\
\text { Aziz and Kamaludin } \\
(2015)\end{array}$ \\
\hline $\begin{array}{l}\text { I will satisfy if the website can make me feel comfortable to } \\
\text { get the information with it }\end{array}$ & $\begin{array}{l}\text { Aziz and Kamaludin } \\
\text { (2015) }\end{array}$ \\
\hline \multicolumn{2}{|l|}{ Visual Appeal } \\
\hline I will satisfy if the text on the website can be easy to read. & $\begin{array}{l}\text { Lioacono et al. (2007) } \\
\text { Aziz and Kamaludin } \\
(2015)\end{array}$ \\
\hline $\begin{array}{l}\text { I will satisfy if the website use the color and structures that } \\
\text { are comfortable to watch. }\end{array}$ & $\begin{array}{l}\text { Lee and Kozar (2012) } \\
\text { Aziz and Kamaludin } \\
(2015)\end{array}$ \\
\hline $\begin{array}{l}\text { I will satisfy if the layout of the pages can make the } \\
\text { information searching process more comfortable. }\end{array}$ & $\begin{array}{l}\text { Liu, Chen, Sun, Wible } \\
\text { and Kuo (2009) }\end{array}$ \\
\hline $\begin{array}{l}\text { I will satisfy if the website look professionally designed and } \\
\text { well presented. }\end{array}$ & Cyr and Dash (2008) \\
\hline $\begin{array}{l}\text { I will satisfy if the product information provided on the } \\
\text { website presented consistently and logically. }\end{array}$ & Cyr and Dash (2008) \\
\hline \multicolumn{2}{|l|}{ Information Quality } \\
\hline $\begin{array}{l}\text { I will satisfy if the content provided by the website can be } \\
\text { easily understood. }\end{array}$ & $\begin{array}{l}\text { Lee and Kozar (2012) } \\
\text { Aziz and Kamaludin } \\
(2015)\end{array}$ \\
\hline $\begin{array}{l}\text { I will satisfy if the content on the website reflects the } \\
\text { company expertise. }\end{array}$ & Corritore et al. (2005) \\
\hline
\end{tabular}




\begin{tabular}{|c|c|}
\hline I will satisfy if the website provide an accurate information. & $\begin{array}{l}\text { Wang, Tang and Tang } \\
\text { (2001) }\end{array}$ \\
\hline I will satisfy if the website provide up-to-date information. & $\begin{array}{l}\text { Wang, Tang and Tang } \\
(2001)\end{array}$ \\
\hline $\begin{array}{l}\text { I will satisfy if the website information adequately meet my } \\
\text { need. }\end{array}$ & $\begin{array}{l}\text { Wang, Tang and Tang } \\
\text { (2001) }\end{array}$ \\
\hline \multicolumn{2}{|l|}{ Information Relevancy } \\
\hline I will satisfy if the website provide truthful information. & Corritore et al. (2005) \\
\hline $\begin{array}{l}\text { I will satisfy if the website can reflect integrity of the } \\
\text { company. }\end{array}$ & Corritore et al. (2005) \\
\hline $\begin{array}{l}\text { I will satisfy if the information provided on the website are } \\
\text { believable. }\end{array}$ & Corritore et al. (2005) \\
\hline $\begin{array}{l}\text { I will satisfy if information such as price, company license, } \\
\text { include and exclude items in the package provided is clear. }\end{array}$ & $\begin{array}{l}\text { Wang, Tang and Tang } \\
\text { (2001) }\end{array}$ \\
\hline $\begin{array}{l}\text { I will satisfy if the website can provide a clear information } \\
\text { about the company background. }\end{array}$ & $\begin{array}{l}\text { Wang, Tang and Tang } \\
\text { (2001) }\end{array}$ \\
\hline $\begin{array}{l}\text { I will satisfy if the website can provide a clear Umrah } \\
\text { package information (Distance of hotel, type of } \\
\text { accommodation, type of flight and many more). }\end{array}$ & $\begin{array}{l}\text { Aziz and Kamaludin } \\
\qquad(2015)\end{array}$ \\
\hline \multicolumn{2}{|l|}{$\begin{array}{c} \\
\end{array}$} \\
\hline $\begin{array}{l}\text { I can trust the website if I satisfy with the website navigation } \\
\text { system. }\end{array}$ & $\begin{array}{l}\text { Aziz and Kamaludin } \\
\text { (2015) }\end{array}$ \\
\hline $\begin{array}{l}\text { I think Umrah Travel Agency website is reliable if the } \\
\text { website links are consistent (easily search). }\end{array}$ & $\begin{array}{l}\text { Aziz and Kamaludin } \\
(2015)\end{array}$ \\
\hline $\begin{array}{l}\text { I feel confident dealing with the website if the website easy } \\
\text { to be used. }\end{array}$ & Corritore at al. (2005) \\
\hline $\begin{array}{l}\text { I think Umrah Travel Agency website is reliable if the } \\
\text { website text is easy to read. }\end{array}$ & $\begin{array}{l}\text { Aziz and Kamaludin } \\
\text { (2015) }\end{array}$ \\
\hline $\begin{array}{l}\text { I think Umrah Travel Agency website is trustworthy if the } \\
\text { website looks professional. }\end{array}$ & Cyr and Dash (2008) \\
\hline $\begin{array}{l}\text { I feel confident dealing with the website if I satisfy with its } \\
\text { visual appeal. }\end{array}$ & Cyr and Dash (2008) \\
\hline $\begin{array}{l}\text { I think Umrah Travel Agency website is trustworthy if it } \\
\text { provides accurate information. }\end{array}$ & $\begin{array}{l}\text { Wang, Tang and Tang } \\
(2001)\end{array}$ \\
\hline $\begin{array}{l}\text { I think Umrah Travel Agency website is reliable if it provides } \\
\text { up-to-date information on it. }\end{array}$ & $\begin{array}{l}\text { Wang, Tang and Tang } \\
(2001)\end{array}$ \\
\hline $\begin{array}{l}\text { I feel confident dealing with the website if I satisfy with the } \\
\text { quality information provided in it. }\end{array}$ & Cyr and Dash (2008) \\
\hline $\begin{array}{l}\text { I can trust the Umrah Travel Agency website if it provides a } \\
\text { clear transaction and price information. }\end{array}$ & $\begin{array}{l}\text { Wang, Tang and Tang } \\
\text { (2001) }\end{array}$ \\
\hline $\begin{array}{l}\text { I think Umrah Travel Agency website is dependable if it can } \\
\text { reflect the company integrity. }\end{array}$ & Corritore at al. (2005) \\
\hline $\begin{array}{l}\text { I feel confident dealing with Umrah Travel Agency website } \\
\text { if I satisfy with the relevant information provided in it. }\end{array}$ & Cyr and Dash (2008) \\
\hline \multicolumn{2}{|l|}{\begin{tabular}{|l} 
Purchase Intention \\
\end{tabular}} \\
\hline $\begin{array}{l}\text { I think that the idea of using the website to purchase an Umrah } \\
\text { package is encouraging. }\end{array}$ & $\begin{array}{l}\text { Heijden, Verhagen and } \\
\text { Creemers (2003) }\end{array}$ \\
\hline
\end{tabular}




\begin{tabular}{|l|c|}
\hline $\begin{array}{l}\text { I think that using the website to buy an Umrah package would } \\
\text { be a good idea. }\end{array}$ & $\begin{array}{c}\text { Heijden,Verhagen and } \\
\text { Creemers (2003) }\end{array}$ \\
\hline $\begin{array}{l}\text { I prefer the idea of purchasing tour package or Umrah } \\
\text { package online. }\end{array}$ & $\begin{array}{c}\text { Heijden,Verhagen and } \\
\text { Creemers (2003) }\end{array}$ \\
\hline $\begin{array}{l}\text { I will likely consider purchasing an Umrah package from the } \\
\text { website. }\end{array}$ & $\begin{array}{c}\text { Heijden,Verhagen and } \\
\text { Creemers (2003) }\end{array}$ \\
\hline $\begin{array}{l}\text { Given a chance, I intend to use the Umrah Travel Agency } \\
\text { website to buy an Umrah package. }\end{array}$ & Faizan Ali, 2016) \\
\hline
\end{tabular}

